\title{
EFFECT OF POPULATION DENSITIES OF Pratylenchus brachyurus ON THE GROWTH OF COTTON PLANTS
}

\author{
MÁRIO M. INOMOTO, ALEXANDRE M. C. GOULART ${ }^{*}$, ANDRESSA C. Z. MACHADO* * \\ \& AILTON R. MONTEIRO
}

Departamento de Entomologia, Fitopatologia e Zoologia Agrícola, Escola Superior de Agricultura "Luiz de Queiroz", Universidade de São Paulo, Cx. Postal 9, 13418-900 Piracicaba, SP, Fax: (019) 429-4338, e-mail: mminomot@esalq.usp.br

(Accepted for publication on 04/04/2001)

Corresponding author: Mário M. Inomoto

INOMOTO, M.M., GOULART, A.M.C., MACHADO, A.C.Z. \& MONTEIRO, A.R. Effect of population densities of Pratylenchus brachyurus on the growth of cotton plants. Fitopatologia Brasileira 26:192-196. 2001.

\begin{abstract}
The effect of different population densities of Pratylenchus brachyurus on the growth of cotton (Gossypium hirsutum) plants was studied in three greenhouse experiments, using cultivars IAC 20 and IAC 22. Both cultivars proved to be good hosts to the nematode, which however did not affect

plant height and affected only slightly fresh root weight and dry top weight of both cultivars, even at the highest population density (over 9,000 nematodes/plant).

Key words: lesion nematode, Gossypium hirsutum, host-parasite relationships, tolerance.

\section{RESUMO}

\section{Efeito de densidades populacionais de Pratylenchus brachyurus no crescimento de algodoeiro}

$\mathrm{O}$ efeito de diferentes densidades populacionais de Pratylenchus brachyurus no crescimento de algodoeiro (Gossypium hirsutum) foi estudado utilizando as cultivares IAC 20 e IAC 22, em três experimentos realizados em casa de vegetação. Ambas as cultivares se mostraram boas

hospedeiras de $P$. brachyurus, embora não afetando a altura das plantas e afetando apenas ligeiramente a massa fresca das raízes e a massa seca da parte aérea, mesmo sob a densidade populacional mais alta (acima de 9.000 nematóides/ planta).
\end{abstract}

\section{INTRODUCTION}

Nematodes are serious pests of upland cotton (Gossypium hirsutum L.). The importance of the reniform nematode, Rotylenchulus reniformis Linford \& Oliveira, 1940, and the root-knot nematode, race 3 of Meloidogyne incognita (Kofoid \& White, 1919) Chitwood, 1949 to cotton is widely known. They are considered major nematode pests of cotton (Starr \& Page, 1993). Losses attributed to those species commonly range between eight and $25 \%$ in Brazil and the U.S.A., but can surpass $50 \%$ in certain areas of the U.S.A. (Lordello, 1976; Orr et al., 1982; Heald \& Orr, 1984).

Potential damage by the lesion nematode, Pratylenchus brachyurus (Godfrey, 1929) Filipjev \& S. Stekhoven, 1941, to cotton has not been adequately evaluated, in spite of its worldwide distribution (Fielding \& Hollis, 1956; Sasser, 1972; Tihohod, 1991). Reductions in cotton growth have been attributed to $P$. brachyurus under field conditions (Martin et al., 1951; Lordello \& Arruda, 1957), but experimental trials showing damages caused by that species to cotton plant are

\footnotetext{
${ }^{*}$ CAPES Fellowship

** CNPq Fellowship
}

scarce (Starr \& Page, 1993). In the only experiment related to this topic, Starr \& Mathieson (1985) inoculated cotton plants with different numbers of $P$. brachyurus $(1,000 ; 2,000$; 4,000; 8,000; and 16,000 nematodes/plant), concluding that reductions in plant growth could occur at the highest density. Hussey \& Roncadori (1978) studied the interaction between P. brachyurus (population level of 5,000/plant) and the mycorrhizal fungus Gigaspora margarita Becker \& Hall in cotton, concluding that the nematode did not affect cotton growth. According to Starr \& Page (1993), differences in susceptibility of cotton cultivars and variation in pathogenicity between P. brachyurus populations could explain such contradictory results.

The role of $P$. brachyurus as a pathogen of cotton has not yet been defined based on trials using only American cultivars. Thus, the present study was conducted to evaluate the effect of $P$. brachyurus on growth of two Brazilian cotton cultivars.

\section{MATERIAL AND METHODS}

Three experiments were conducted under greenhouse conditions using upland cotton cultivars IAC 20 and IAC 22, 
selected among eight cultivars tested in a preliminary experiment (Goulart et al., 1997), that indicated highest $P$. brachyurus reproduction on IAC 20 and lowest $P$. brachyurus reproduction on IAC 22. These cultivars were widely used in Brazil until recently. Experiments 1 and 2 were carried out at the "Instituto Agronômico do Paraná", in Londrina, State of Paraná, and experiment 3, at the "Escola Superior de Agricultura Luiz de Queiroz", in Piracicaba, State of São Paulo.

\section{Inoculum preparation}

Two isolates of $P$. brachyurus $(\mathrm{Pb})$ were used, one obtained from corn (Zea mays L.) roots collected in Piracicaba, and the other from okra (Abelmoschus esculentus L.) roots collected in Seropédica (State of Rio de Janeiro). The isolates were monoxenically multiplied on alfalfa (Medicago sativa L.) calli by Riedel et al. (1973) method. Part of the calli or culture media with the nematode was transferred to glass flasks containing calli and culture media without the nematode. After 60 days, the material of the cultures was processed to obtain the inocula. For experiments 1 and 2, both isolates were used. The culture was mixed and then briefly homogenized with tap water in a blender, resulting in an aqueous suspension containing the nematodes, calli and culture media, which were used as inoculum. For experiment 3 , only the okra isolate was used, and $\mathrm{Pb}$ was extracted from cultures by a modification of Baermann method for flat recipient (Hooper, 1986). In this way, an aqueous suspension containing juveniles+adults of $\mathrm{Pb}$ free of calli wastes and culture media was obtained and used as inoculum. For the experiments, the numbers of eggs + juveniles+adults were estimated using a Peters' counting slide under light microscope.

\section{Experiments 1 and 2}

Cotton seeds were pre-germinated in moistened paper at $25{ }^{\circ} \mathrm{C}$ for two days, and transferred to $500 \mathrm{ml}$ plastic pots with soil sterilized with methyl bromide $\left(150 \mathrm{ml} / \mathrm{m}^{3}\right.$ of soil). Inoculations of $\mathrm{Pb}$ were done at the first true leaf stage about ten days after planting by placing the inoculum in two small holes (4 cm deep) in the soil, each $20 \mathrm{~mm}$ from the plant base. Plants of corn cv. IAPAR 51 were inoculated in the same way to confirm inoculum viability. Each corn plant was inoculated with 1,000 nematodes in experiment 1 (with IAC 20 ), and with 2,000 nematodes in experiment 2 (with IAC 22).

The experiments were set in completely randomized designs, with six treatments, corresponding to different $\mathrm{Pb}$ densities: 0 (check); 333; 1,000; 3,000; 9,000; and 27,000 nematodes/plant. Each treatment was replicated eight times, except for the highest density, which was replicated four times. Final nematode population was estimated using four of their replications. Each experiment unit was a single pot with one cotton plant.

Maximum and minimum soil temperatures were registered daily and varied from 22 to $38^{\circ} \mathrm{C}$ and from 10 to $26^{\circ} \mathrm{C}$, respectively, for experiments 1 and 2 .

Plant growth was evaluated during the experiments by measuring plant height 35,48 and 84 days from inoculation for experiment 1, and 45, 76 and 96 days from inoculation for the experiment 2 .

After the final evaluation, plants were cut near the soil surface and the roots were washed, dried for a few minutes, and weighed. Top parts of the plants were dried in a chamber with forced airing at $60^{\circ} \mathrm{C}$ until constant weight was achieved. Reproduction of $\mathrm{Pb}$ was estimated by extracting nematodes from roots and soil and calculating the reproduction rate (Pf/ $\mathrm{Pi}$, where Pf is the nematode final population and $\mathrm{Pi}$ is the nematode initial population, i.e., $\mathrm{Pb}$ inoculum size). Pf was obtained by counting eggs, juveniles and adults extracted from roots and soil, using a Peters' counting slide under light microscope. Nematodes were extracted from roots by Coolen \& D'Herde's (1972) method, and from soil by Jenkins's (1964) method.

\section{Experiment 3}

Seeds of cv. IAC 20 were treated and sown as in experiments 1 and 2, and transferred to a screenhouse where the experiment was conducted. The cotton seedlings were thinned, six days after planting, to keep only one seedling per pot. Inoculation with $\mathrm{Pb}$ was done at the first true leaf stage, about ten days after planting, by placing the inoculum in two small holes ( $4 \mathrm{~cm}$ deep) in the soil, each $20 \mathrm{~mm}$ from the plant base. Four pots containing seedlings of corn cv. IAPAR-26 were also inoculated, with $1,250 \mathrm{~Pb}$ each, to confirm the inoculum viability.

The experiment was set in a completely randomized design, with seven treatments, corresponding to different $\mathrm{Pb}$ densities: 0 (check); 125; 375; 1,125; 3,375; 6,750; and 10,125 nematodes/plant. Each treatment was replicated nine times, and each experiment unit was a single pot with one cotton plant. Final nematode population was estimated using four replications.

Evaluations were done 96 days after inoculations using the same procedures reported for experiments 1 and 2 .

\section{Data analysis}

Regression analysis was used to relate initial nematode populations to growth variables, i.e. plant height, fresh root weight and dry top weight for experiments 1 and 2, and fresh root weight and dry top weight for experiment 3 . A computer program [SANEST (Zonta \& Machado, 1984)] was used to calculate the best-fitting equation, by polynomial regression.

\section{RESULTS}

\section{Experiments 1 and 2}

Data of plant height, fresh root weight, and dry top weight of both cultivars studied are shown in Tables 1 and 2 . Variation of fresh root weight of cultivar IAC 20 with increasing populations of the nematode was significant at a $5 \%$ level of probability. The following equation was 
determined to relate fresh root weight of $\mathrm{cv}$. IAC 20 with initial inoculum:

$$
\mathrm{Y}=9.206987-0.0001050 \mathrm{x}
$$

where $\mathbf{y}$ is the fresh root weight $(\mathrm{g})$ and $\mathbf{x}$ is the initial population density (nematodes/plant). The equation estimates that the fresh roots of uninoculated plants weigh approximately $9.2 \mathrm{~g}$, and that 9,520 nematodes are necessary to decrease each gram of fresh root weight.

A significant effect of $\mathrm{Pb}$ population densities on dry top weight was observed for both cultivars. For cv. IAC 20, the regression was significant at a $5 \%$ level of probability, and the following equation was obtained:

$$
\mathrm{Y}=5.268231-0.0000423 \mathrm{x}
$$

where $\mathbf{y}$ is the dry top weight (grams) and $\mathbf{x}$ is the initial population density (nematodes/plant). It is estimated that the dry shoots of non inoculated plants weigh approximately 5.3 $\mathrm{g}$, and that 23,640 nematodes are necessary to decrease each gram of dry shoot weight.

For cv. IAC 22, the regression was significant at a $1 \%$ level of probability, and the equation obtained was:

$$
Y=4.667567-0.0000406 x
$$

where $\mathrm{y}$ is the dry top weight $(\mathrm{g})$ and $\mathrm{x}$ is the initial population density (nematodes/plant). It is estimated that the dry shoots of uninoculated plants weigh approximately $4.7 \mathrm{~g}$, and that 24,630 nematodes are necessary to decrease each gram of dry shoot weight.

The mean numbers of nematodes extracted from roots and soil at the end of the experiments (Tables 1 and 2) showed that as expected, there was an inverse correlation between initial population densities of $\mathrm{Pb}$ and the rate of reproduction, which might be due to intraspecific competition for sites available for parasitism per plant (Di Vito et al., 1986).

\section{Experiment 3}

Data of fresh root weight and dry top weight of cv.
IAC 20 (Table 3) showed that regressions were not significant for either variable, indicating that none of the densities used affected growth of cotton cv. IAC 20.

\section{DISCUSSION}

Effects of $\mathrm{Pb}$ on cotton root fresh weight, dry top weight and plant height were observed only in experiments 1 and 2, probably because of the higher population densities used in those experiment. The regression equations obtained for fresh root weight and dry top weight in experiments 1 and 2 showed that $\mathrm{Pb}$ affected cotton growth only slightly, as indicated by the low value of $\mathrm{Pb}$ in the regression equations, ranging from 0.0000406 to 0.0001050 . Cotton growth was reduced only with high population densities of $\mathrm{Pb}$. Actually, fresh root weight of cv. IAC 20 and IAC 22 in experiments 1 and 2 was somewhat enhanced by the three lowest dosages of $\mathrm{Pb}(333,1,000$ and 3,000 nematodes/plant), probably due to the production of new roots to compensate for damages by $\mathrm{Pb}$, resulting in increased root weight. This defense reaction would be effective only for low levels of $\mathrm{Pb}$, since higher nematode levels apparently prevented this sort of reaction by the plant.

Present data indicate that $\mathrm{Pb}$ is a weak cotton pathogen, as pointed out by previous authors. According to Sasser (1972) there was not enough evidence that Pratylenchus spp. were pathogenic to cotton. Hussey \& Roncadori (1978) observed in a greenhouse experiment that $\mathrm{Pb}$ did not affect growth of cotton plants at a density of 5,000 nematodes/plant. Starr \& Mathieson (1985) showed that $\mathrm{Pb}$ damaged cotton growth only at a population density of 16,000 nematodes/plant.

The data on reproduction showed that cotton is a good host for the nematode, as reported in most previous studies (Hussey \& Roncadori, 1978; Goulart et al., 1997; Johnson et al., 1998). Only Starr \& Mathieson (1985) concluded that cotton was probably a poor host for $\mathrm{Pb}$. Our results suggest that at least cotton cv. IAC 20 and IAC 22 are tolerant hosts of this nematode, according to the conceptions of Dropkin \& Nelson (1960). This is the main result of the present work, and indicates that these cultivars are only significantly affected at high $\mathrm{Pb}$ population levels.

TABLE 1 - Plant height, fresh root weight and dry top weight of cotton (Gossypium hirsutum) cv. IAC 20 inoculated with different Pratylenchus brachyurus densities (means of

\begin{tabular}{|c|c|c|c|c|c|c|}
\hline \multirow{2}{*}{$\begin{array}{c}\text { Treatment } \\
\text { (nematodes/plant) }\end{array}$} & \multicolumn{3}{|c|}{ Plant height (cm) } & \multirow{2}{*}{$\begin{array}{l}\text { Fresh root } \\
\text { weight (g) }\end{array}$} & \multirow{2}{*}{$\begin{array}{c}\text { Dry top } \\
\text { weight (g) }\end{array}$} & \multirow{2}{*}{$\mathbf{P f} / \mathbf{P i}$} \\
\hline & 35 days & 48 days & 84 days & & & \\
\hline 0 & 23.5 & 28.3 & 33.4 & 8.44 & 5.36 & 0 \\
\hline 333 & 23.2 & 28.0 & 33.0 & 9.66 & 5.38 & 2.54 \\
\hline 1,000 & 23.4 & 28.4 & 33.3 & 9.21 & 5.54 & 1.98 \\
\hline 3,000 & 20.0 & 24.4 & 28.3 & 9.04 & 4.77 & 1.92 \\
\hline 9,000 & 22.8 & 26.3 & 30.0 & 8.35 & 4.60 & 0.89 \\
\hline 27,000 & 21.4 & 24.4 & 29.4 & 6.26 & 4.38 & 0.29 \\
\hline Corn 1,000 & - & - & - & - & - & 6.28 \\
\hline
\end{tabular}
eight replications $\left.{ }^{1}\right)$, and reproduction rate $(\mathrm{Pf} / \mathrm{Pi})$ of $P$. brachyurus in cotton and corn (Zea mays) plants (means of four replications for cotton and five for corn)

${ }^{1}$ Except for 27,000 nematodes, which had four replications 
Effect of population densities of Pratylenchus brachyurus on the growth...

TABLE 2 - Plant height, fresh root weight and dry top weight of cotton (Gossypium hirsutum) cv. IAC 22 inoculated with different Pratylenchus brachyurus densities (means of eight replications $\left.{ }^{1}\right)$, and reproduction rate $(\mathrm{Pf} / \mathrm{Pi})$ of $P$. brachyurus in cotton and corn (Zea mays) plants (means of four replications for cotton and eight for corn)

\begin{tabular}{|c|c|c|c|c|c|c|}
\hline \multirow{2}{*}{$\begin{array}{c}\text { Treatment } \\
\text { (nematodes/plant) }\end{array}$} & \multicolumn{3}{|c|}{ Plant height $(\mathrm{cm})$} & \multirow{2}{*}{$\begin{array}{l}\text { Fresh root } \\
\text { weight (g) }\end{array}$} & \multirow{2}{*}{$\begin{array}{c}\text { Dry top } \\
\text { weight (g) }\end{array}$} & \multirow{2}{*}{$\mathbf{P f} / \mathbf{P i}$} \\
\hline & 45 days & 76 days & 96 days & & & \\
\hline 0 & 20.1 & 26.5 & 29.3 & 5.31 & 4.60 & 0 \\
\hline 333 & 21.7 & 27.2 & 31.4 & 5.95 & 4.82 & 4.00 \\
\hline 1,000 & 21.2 & 27.2 & 30.7 & 5.40 & 4.59 & 3.31 \\
\hline 3,000 & 21.3 & 26.6 & 30.7 & 5.44 & 4.54 & 1.17 \\
\hline 9,000 & 22.4 & 28.7 & 32.2 & 4.77 & 4.23 & 0.70 \\
\hline 27,000 & 20.1 & 23.7 & 28.6 & 4.81 & 3.62 & 0.28 \\
\hline Corn 1,000 & - & - & - & - & - & 2.96 \\
\hline
\end{tabular}

${ }^{1}$ Except for 27,000 nematodes, which had four replications

TABLE 3 - Fresh root weight and dry top weight of cotton (Gossypium hirsutum) cv. IAC 20 inoculated with different Pratylenchus brachyurus densities (means of nine replications), and reproduction of $P$. brachyurus in cotton and corn (Zea mays) plants (means of four replications)

\begin{tabular}{|c|c|c|c|c|}
\hline $\begin{array}{c}\text { Treatment } \\
\text { (nematodes/plant) }\end{array}$ & $\begin{array}{l}\text { Fresh root } \\
\text { weight (g) }\end{array}$ & $\begin{array}{c}\text { Dry top } \\
\text { weight (g) }\end{array}$ & Pf roots & $\mathrm{Pf} / \mathrm{Pi}$ \\
\hline Check & 7.69 & 10.35 & 0 & 0 \\
\hline 125 & 8.33 & 10.62 & 987 & 7.89 \\
\hline 375 & 7.49 & 9.55 & 1,198 & 3.19 \\
\hline 1,125 & 7.58 & 10.55 & 2,848 & 2.53 \\
\hline 3,375 & 5.74 & 9.45 & 5,882 & 1.74 \\
\hline 6,750 & 8.08 & 11.05 & 14,246 & 2.10 \\
\hline 10,125 & 7.28 & 9.25 & 18,373 & 1.81 \\
\hline Corn 1,000 & - & - & 12,887 & 11.45 \\
\hline
\end{tabular}

It is also possible that other factors, such as water stress, nutritional imbalance, and soil compaction could enhance the damages caused by $\mathrm{Pb}$ to cotton. Such factors are minimized in greenhouse experiments when plants are adequately irrigated and fertilized. Stresses of these types may explain why previous reports have shown that on some cotton plantations, mainly in Brazil, plants infected by $\mathrm{Pb}$ had poor development, showed symptoms of mineral deficiencies and had low yield (Lordello \& Arruda, 1957; Ferraz \& Lordello, 1961). Knolls with cotton plants infected by $\mathrm{Pb}$ and exhibiting brown root rot were reported in Louisiana, the United States (Martin et al., 1951).

Another important implication of the good reproduction of $\mathrm{Pb}$ on cotton is that it may not be appropriated for production systems involving rotation crops such as corn (Zea mays L.), sugarcane (Saccharum sp.), coffee (Coffea arabica L.), peanut (Arachis hypogaea L.), soybean [Glycine max (L.) Merr.] and haricot bean (Phaseolus vulgaris L.), which are severally damaged by this nematode. Johnson et al. (1998) reported that cotton increased $\mathrm{Pb}$ population in crop sequences with triticale (Triticosecale Whittmack) and soybean. So the effect of cotton on $\mathrm{Pb}$ population in soil must be considered before planning a crop sequence.

\section{ACKNOWLEDGEMENTS}

Special thanks to Dr. Gilberto M. de Moraes, from ESALQ/USP for his suggestions and manuscript review.

\section{LITERATURE CITED}

COOLEN, W.A. \& D'HERDE, C.J. A method for the quantitative extraction of nematodes from plant tissue. Ghent. Min. Agr. Sta. Adm. Centre.1972.

DI VITO, M., GRECO, N. \& CARELLA, A. Effect of Meloidogyne incognita and importance of the inoculum on the yield of eggplant. Journal of Nematology 18:487490. 1986.

DROPKIN, V.H. \& NELSON, P.E. The histopathology of rootknot nematode infections in soybean. Phytopathology 50:442-447. 1960.

FERRAZ, C.A.M. \& LORDELLO, L.G.E. Interferência de nematódeos em culturas de algodão. Revista de Agricultura 36:131-138. 1961.

FIELDING, M.J. \& HOLLIS, J.P. Occurrence of plant parasitic nematodes in Louisiana soils. Plant Disease Reporter 40:403-405. 1956.

GOULART, A.M.C., INOMOTO, M.M. \& MONTEIRO, A.R. Hospedabilidade de oito cultivares de algodoeiro a Pratylenchus brachyurus. Nematologia Brasileira 21:111-118, 1997.

HEALD, C.M. \& ORR, C.C. Nematodes parasites of cotton. In: Nickle, W.R. (Ed.) Plant and Insect Nematodes. New York. Marcel Dekker, 1984. pp. 147-166.

HOOPER, D.J. Extraction of free-living stages from soil. In: Southey, J.F. (Ed.) Laboratory methods for work with plant and soil nematodes. London. Her Majesty's Stationery Office.1986. pp.5-30.

HUSSEY, R.S. \& RONCADORI, R.W. Interaction of Pratylenchus brachyurus and Gigaspora margarita on cotton. Journal of Nematology 10:6-20. 1978.

JENKINS, W.R. A rapid centrifugal-flotation technique for separating nematodes from soil. Plant Disease Reporter 48:692. 1964.

JOHNSON, A.W., DOWLER, C.C., BAKER, S.H. \& 
HANDOO, Z.A. Crop yields and nematode population densities in triticale-cotton and triticale-soybean rotations. Journal of Nematology 30:353-361. 1998.

LORDELLO, L.G.E. Perdas causadas por nematóides. Revista de Agricultura 51:222. 1976.

LORDELLO, L.G.E. \& ARRUDA, H.V. Nota prévia acerca da ocorrência de nematódeos do gênero Pratylenchus em raízes de algodoeiro. O Solo 49:33-34. 1957.

MARTIN, W.J., NEWSON, L.D. \& SCHWEGMANN, J. Nematode root rot of cotton in Louisiana. Plant Disease Reporter 35:8. 1951.

ORR, C.C., ROBINSON, A.R., HEALD, C.M., VEECH, J.A. \& CARTER, W.W. Estimating cotton losses to nematodes. Proceedings. Beltwide Cotton Production Research Conference, Las Vegas.1982. pp.22.

RIEDEL, R.M., FOSTER, J.G. \& MAI, W.F. A simplified medium for monoxenic culture of Pratylenchus penetrans and Ditylenchus dipsaci. Journal of Nematology 5:71-72. 1973.

SASSER, J.N. Nematodes diseases of cotton. In: Webster,
J.M. (Ed.). Economic Nematology. London. Academic Press. 1972. pp. 187-214.

STARR, J.L. \& MATHIESON, T. Reproduction of Pratylenchus brachyurus on cotton and growth response to infection by the nematode. Proceedings. Beltwide Cotton Production Research Conference, New Orleans. 1985. pp. 25.

STARR, J.L. \& PAGE, L.J. Nematode parasites of cotton and other tropical fibber crops. In: Luc, M., R.A. Sikora \& Bridge, J. (Ed.). Plant Parasitic nematodes in subtropical and tropical agriculture. Wallingford. CAB International. 1993. pp. 539-556.

TIHOHOD, D. Controle de nematóides parasitos do algodoeiro através de sequiência de culturas e avaliação de métodos de amostragem e extração. ( $\mathrm{PhD}$ Thesis). Jaboticabal, Universidade Estadual Paulista. 1991.

ZONTA, E.P. \& MACHADO, A.A. Sistema de análise estatística para microcomputadores - SANEST. Pelotas, 1984 (apostila). 